Dr Lidia Dakowicz*, https://orcid.org/0000-0001-6424-1370

Dr Andrzej Dakowicz*, https:// orcid.org/0000-0002-3614-8985

*Faculty of Education

University of Bialystok

\title{
The Quality of Marital Communication of Spouses with a Higher and Lower Level of Satisfaction with their Relationship
}

\author{
Jakość komunikacji małżeńskiej małżonków \\ o wyższym i niższym poziomie zadowolenia \\ ze swojego związkư ${ }^{1}$
}

https://doi.org/10.34766/fetr.v46i2.797

\begin{abstract}
Seventy-five marriage couples were investigated in the study. According to M. BraunGałkowska's Marital Success Scale, two groups were distinguished, of 30 couples each, with higher and lower levels of satisfaction with their relationship. The quality of marital communication was determined on the basis of the results of the Communication in Marriage Questionnaire by M. Kaźmierczak and M. Plopa, which presents it in terms of support, commitment and depreciation. Spouses with a higher level of satisfaction with their relationship are characterized by a higher quality of communication, especially in terms of mutual commitment and support in everyday life of their marriage.
\end{abstract}

Keywords: marriage, marriage satisfaction, marital communication, support, commitment, depreciation

\begin{abstract}
Abstrakt: Badaniom poddano 75 par małżeńskich, spośród których na podstawie wyniku Skali Powodzenia Małżeństwa M. Braun-Gałkowskiej, wyróżniono po 30 małżeństw o wyższym i niższym poziomie zadowolenia ze swojego związku. Jakość komunikacji małżeńskiej określono w oparciu o wyniki Kwestionariusza Komunikacji Małżeńskiej M. Kaźmierczak i M. Plopy, który ujmuje ją $\mathrm{w}$ aspekcie udzielanego wsparcia, zaangażowania i deprecjacji. Małżonkowie o wyższym poziomie zadowolenia ze swojego związku charakteryzują się wyższą jakością komunikacji, szczególnie $\mathrm{w}$ aspekcie wzajemnego zaangażowania i udzielania sobie wsparcia $\mathrm{w}$ codzienności życia małżeńskiego.
\end{abstract}

Słowa kluczowe: małżeństwo, zadowolenie z małżeństwa, komunikacja małżeńska, wsparcie, zaangażowanie, deprecjacja

\section{Introduction}

The relationship between marriage mates provides the basis for family functioning (Sorkowicz, 2021) and contributes the most to the atmosphere in the family (Dakowicz,

\footnotetext{
${ }^{1}$ Wersja w języku polskim na stronie:

https://www.stowarzyszeniefidesetratio.pl/Presentations0/2021-2-07Dakowicz2.pdf
} 
2020). The spouses naturally expect to have a relationship that would be satisfying for both of them. Some couples do achieve this, while others do not, which results in the deterioration of their relationship and ultimately, the decision to end the marriage in divorce (Paprzycka, Mianowska, 2020). The quality of marital relationship is determined by factors occurring both before and after the wedding (Weryszko, 2020a). If the future spouses had parents who were satisfied with their marriage, they are usually able to establish close, constructive relations with their partner (Wańczyk-Welc, Marmola, 2020). To maintain and develop interpersonal relations, you need the appropriate level of intellectual, personal, emotional, social and psychosexual development (Rostowska, 2003).

Experiencing courtship, learning about each other, and in particular, conscious engagement in preparation to marriage, modify the quality of the future marital relationship. Participation in premarital education helps achieve a higher level of marital satisfaction and commitment in the marriage, and a lower frequency of conflicts and likelihood of divorce (Cobb, Sullivan, 2015; Chrząstowski, 2020). Longitudinal studies concerning the dependencies between the quality of communication during courtship and satisfaction with the marriage clearly show a positive impact of communication full of support and commitment on satisfaction with marriage and a negative impact of depreciating communication on satisfaction with marriage (Weryszko, 2012). The higher the level of anxiety during courtship, the lower the satisfaction during marriage. High expectations of the marriage in the engagement period, which can be treated as an expression of high aspirations motivating to act for the good of the relationship, lead to increased satisfaction with marriage (Ulfik-Jaworska, 2012).

The more and more frequent phenomenon of cohabiting before the wedding has a negative impact on the quality of the future marriage (Ulfik-Jaworska, 2015). Couples living together before the marriage have a lower quality relationship afterwards, reduced trust in the institution of marriage, and a higher likelihood of dissolution of the marriage (Raley, Sweeney, 2020), especially in the case of cohabiting more than once (Janicka, Cieślak, 2020). The higher divorce rate in marriages preceded by cohabitation is connected with lower commitment to the institution of marriage and higher individualism developed in the cohabitation period (Janicka, 2010).

Sexual initiation before the wedding may have a positive or negative influence on the quality of marriage. If the first sexual contact was satisfying, the partners consider it as having a beneficial influence on the development of their relationship. If, however, the women feel pressured by their partners to engage in sexual activity, it has a negative impact on the relationship they are in and lowers the quality of the marriage (Jankowiak, Waszyńska, 2011). The basic conditions that can only be met in a marriage, contributing to satisfaction with a sexual intercourse, include love, engagement in gradual and proper development of the love relationship, its sexual and non-sexual expressions, rituals and 
celebrations, joyfully waiting while displaying temperance, exclusiveness, faithfulness and responsibility (Kornas-Biela, 2012). The quality of the relationship and the character of mutual relations between the partners before the wedlock may be a good prognostic indicator of their married life in the future (Chmielewska, 2019). Involvement in building high quality relationship before the wedding provides a good foundation for the marriage, allowing its further development afterwards, ensuring the quality that gives the sense of satisfaction to both spouses.

\section{Marital communication as one of the factors influencing the sense of satisfaction with the relationship}

The atmosphere of marriage life is basically shaped by both spouses, who express themselves in various ways because of their personality determinants, such as temperament and intelligence, which are hardly modifiable (Hill et al., 2018; Lengua, Gartstein, Prinzie, 2019). With regard to temperamental characteristics dictating specific styles of responding in particular situations of married life (Rawicka, Rzepa, 2017), researchers have sought to identify more and less favorable combinations of temperamental types of husbands and wives (Juroszek, 2017). However, we need to remember that they exist in a broader context of complex personality, so the couples may manifest them in various ways. The spouses' level of classical intelligence, understood as the ability to cope in new situations through the use of thinking resources, is insignificant for marital satisfaction (Dakowicz, 2014). But as regards emotional intelligence, understood as a set of abilities determining the use of emotions when solving problems (Jaworowska, Matczak, 2001), its higher level leads to increased sense of satisfaction with the marriage relationship (Erus, Deniz, 2020). Marital satisfaction is also promoted by the partners' empathy and open-mindedness (Weryszko, 2020b). Empathic care and accepting the mate's perspective forms your positive image in their eyes (Chrost, 2020) and encourages them to express support and commitment through communication (Siemiątkowska, Obrębska, 2020). These characteristics can largely be attributed to androgyny, i.e., the person having a high level of feminine (expressive) and masculine (instrumental) traits at the same time (Wołpiuk-Ochocińska, 2020), which helps satisfy the need of security (Dakowicz, 2002). The positive impact of expressive traits on spouses' relationship, manifested in greater orientation at another person, can be explained by the intimate nature of marital relationship. It is much more important than their efficiency in doing tasks (Szyszka, 2020). Fuller satisfaction of the natural desire for intimacy and tenderness of the partner gives you the sense of happiness, which produces the atmosphere of marital relationship satisfying for both sides (Mandal, 2004). A similar trait that is also very important in a close interpersonal relationship is intimacy, understood as a positive feeling and related activity causing affection, closeness and mutual dependence (Wojciszke, 
2017). A high level of intimacy reduces the risk of depression and anxiety symptoms (Ryś, Greszta, Grabarczyk, 2019). Just like in the case of religiosity, there is a regularity that a higher level of intimacy makes the spouses more engaged in overcoming the emerging difficulties, especially through working on their own personality and through marital dialog (Dakowicz, 2013; Trębicka, Cichocka, 2019; Mahoney, Flint, McGraw, 2020; Rucki, 2020).

A marriage is a special form of close interpersonal relation (Adler, Rosenfeld, Proctor II, 2007, p. 442), assumed to be lifelong, whose goal is to achieve the common good by creating a multi-aspect community of life (Braun-Gałkowska, 1985, pp. 17-18). Marriage mates influence each other on many planes, engaging in the incessant process of interaction, thus creating the atmosphere in their marriage (Braun-Gałkowska, 2020), which naturally requires agreement and dialog (Breton, 2020; Jabłońska, 2020). Usually, at the beginning of their life together, the spouses focus on communicating directly, which then gradually changes into indirect communication. Consequently, the level of expressiveness and relationship control lowers and the range of issues regarded as obvious grows. More and more family rituals, personal beliefs and intuitive understanding become part of communication between the partners (Kuryś-Szyncel, Błachnio, 2020). Living together with the marriage mate leads to natural changes, which involve normative crises, cause various conflicts related to the loss of purpose in life, faith, changes in the system of values, ethics, or trust in another person (Pyźlak, 2020), and the way of solving those conflicts modifies the quality of the marital relationship (Otero et al., 2020).

\section{Methodology}

The study attempted to determine whether the quality of marital communication differentiates between spouses with a higher and lower level of satisfaction with their relationship. The review of source literature justifies the assumption that spouses with a higher level of satisfaction with their marriage also display a higher quality of marital communication.

The research involved married couples living in or around Białystok, in the first formal marriage lasting for at least 5 years, with secondary or higher education, professionally active and having two children. The study was carried out by the participants of a master's degree seminar conducted in the years 2014-2016 at the Institute of Social Psychology and Human Development at the Faculty of Pedagogy and Psychology of the University of Bialystok ${ }^{2}$. Each seminar participant was asked to investigate families meeting the assumed criteria. The study was conducted using the Marital Success Scale (Braun-

2 The research was carried out in 2015 by: Wioleta Birycka, Katarzyna Bułynko, Emilia Dylewska, Milena Chełmińska, Katarzyna Jaroszuk, Wiktoria Karpowicz, Anna Kułak, Urszula Kułak, Katarzyna Pruszyńska, Aleksandra Sokolik, Karol Suprun, Arlena Szpakowska, Agnieszka Zalewska, Dagmara Zieniuk. 
Gałkowska, 2007) and the Communication in Marriage Questionnaire (Kaźmierczak, Plopa, 2005).

Following the assumed research procedure produced complete results for 75 families. On the basis of the score obtained in the Marital Success Scale (Braun-Gałkowska, 2007), two groups of 30 couples with a higher and lower level of satisfaction with their marriage were determined.

Table 1. Characteristics of study groups

\begin{tabular}{|c|c|c|c|c|c|}
\hline \multirow{2}{*}{\multicolumn{2}{|c|}{$\begin{array}{c}\text { Selected characteristics of } \\
\text { spouses }\end{array}$}} & \multicolumn{2}{|c|}{$\begin{array}{l}\text { Spouses with a higher level of } \\
\text { satisfaction with their marriage }\end{array}$} & \multicolumn{2}{|c|}{$\begin{array}{l}\text { Spouses with a lower level of } \\
\text { satisfaction with their marriage }\end{array}$} \\
\hline & & $\begin{array}{l}\text { Wives } \\
(\mathrm{N}=30)\end{array}$ & $\begin{array}{l}\text { Husbands } \\
(\mathrm{N}=30)\end{array}$ & $\begin{array}{l}\text { Wives } \\
(\mathrm{N}=30)\end{array}$ & $\begin{array}{l}\text { Husbands } \\
(\mathrm{N}=30)\end{array}$ \\
\hline \multicolumn{2}{|l|}{ Age (mean) } & 40.4 & 41.1 & 40.4 & 41.9 \\
\hline \multirow{2}{*}{$\begin{array}{l}\text { Education } \\
\text { level } \\
\mathrm{N}(\%)\end{array}$} & Higher & $20(66.7 \%)$ & $14(46.7 \%)$ & $19(63.3 \%)$ & $13(43.3 \%)$ \\
\hline & Secondary & $10(33.3 \%)$ & $16(53.3 \%)$ & $11(36.7 \%)$ & $17(56.7 \%)$ \\
\hline \multicolumn{2}{|c|}{ Length of marriage (mean) } & \multicolumn{2}{|c|}{16.2} & \multicolumn{2}{|c|}{16.9} \\
\hline \multirow{2}{*}{$\begin{array}{l}\text { Children's sex } \\
\mathrm{N}(\%)\end{array}$} & Girl & \multicolumn{2}{|c|}{$29(48.3 \%)$} & \multicolumn{2}{|c|}{$36(60.0 \%)$} \\
\hline & Boy & \multicolumn{2}{|c|}{$31(51.7 \%)$} & \multicolumn{2}{|c|}{$24(40.0 \%)$} \\
\hline \multirow{2}{*}{$\begin{array}{l}\text { Children's age } \\
\text { (mean) }\end{array}$} & Girl & \multirow{2}{*}{\multicolumn{2}{|c|}{$\begin{array}{l}12.5 \\
13.4 \\
\end{array}$}} & \multicolumn{2}{|c|}{$\frac{14.4}{13.8}$} \\
\hline & Boy & & & & \\
\hline
\end{tabular}

In the group of couples with a higher level of satisfaction with their marriage, the mean level of satisfaction among wives was 82.8 (the lowest - 67, the highest - 100), and among husbands, 86.4 (the lowest -65 , the highest - 100). The mean length of their marriage was 16.2 years. The mean age of the wives was 40.4, and of the husbands, 41.1. The wives with the higher level of satisfaction with marriage more often had higher education $(66.7 \%)$ than secondary education (33.3\%). In the case of husbands, there was a reverse tendency: the husbands with a higher level of satisfaction with marriage more often had secondary education $(53.3 \%)$ than higher education $(46.7 \%)$. In the group of couples with a lower level of satisfaction with their marriage, the mean level of satisfaction among wives was 45.1 (the lowest -6 , the highest -90), and among husbands, 49.0 (the lowest -8 , the highest - 95). The mean length of their marriage was 16.9 years, the mean age of wives was 40.4 , and husbands, 41.9. The wives with a lower level of satisfaction with marriage more often had higher education $(63.3 \%)$ than secondary education $(36.7 \%)$, and the husbands more often had secondary edu $56.7 \%)$ than higher education (43.3\%)

The quality of marital communication was determined using the Communication in Marriage Questionnaire by M. Kaźmierczak and M. Plopa (2005). Following the assumption that one of the basic tasks of married couples is to acquire specific knowledge connected with the system of rules of communication in an intimate relationship, the authors prepared two versions of a 30-item questionnaire (to assess oneself or the spouse). In the research project, we used the version concerning the assessment of the spouse in 5 variants: from 1 - "never" (my spouse never behaves like that) to 5 - "always" (my spouse always behaves 
like that). The conducted analyses produced three dimensions of marital communication whose level of saturation modifies the quality of their relationships:

1) Support (10 items) - showing respect to the partner by appreciating their efforts, displaying interest in their problems and needs, and active participation in the process of solving problems together;

2) Commitment (9 items) - the ability to create the atmosphere of mutual understanding and intimacy in the relationship by showing affection to each other, stressing the uniqueness and importance of our partner, breaking the everyday routine, and preventing conflicts in the relationship;

3) Depreciation (11 items) - displaying aggression toward the partner, the wish to dominate and control their activities, no respect for their dignity.

Thanks to the high psychometric values of the research instrument (Plopa, 2005), the Communication in Marriage Questionnaire can be used to assess the marital communication of the studied population.

The research results were analyzed with the computer program SPSS 24.0 PL for Windows, used to calculate the $t$-Student test value for the compared groups (Cypryańska, Bedyńska, 2013, pp. 179-184).

\section{Results}

The study results concerning interpersonal communication of spouses from the compared groups show differences reaching the level of statistical significance, both for the wives (table 2, chart 1) and for the husbands (table 3, chart 2).

Table 2. Marital communication of wives with a higher and a lower level of satisfaction with their marriage

\begin{tabular}{|l|c|c|c|c|c|c|}
\hline \multirow{2}{*}{ Scale } & \multicolumn{2}{|c|}{$\begin{array}{c}\text { Wives with a higher level } \\
\text { of satisfaction }(\mathrm{N}=30)\end{array}$} & \multicolumn{2}{c|}{$\begin{array}{c}\text { Wives with a lower level } \\
\text { of satisfaction }(\mathrm{N}=30)\end{array}$} & \multicolumn{2}{c|}{$\begin{array}{c}\text { Significance of } \\
\text { differences }\end{array}$} \\
\cline { 2 - 7 } & $\mathrm{M}$ & $\mathrm{SD}$ & $\mathrm{M}$ & $\mathrm{SD}$ & $\mathrm{t}$ & $\mathrm{p}<$ \\
\hline Support & 40.83 & 6.62 & 36.17 & 6.66 & 2.72 & 0.01 \\
\hline Commitment & 32.77 & 5.48 & 27.83 & 5.50 & 3.48 & 0.01 \\
\hline Depreciation & 45.47 & 5.30 & 42.07 & 7.82 & 1.97 & 0.05 \\
\hline Total score & 120.27 & 13.42 & 106.07 & 15.53 & 3.79 & 0.01 \\
\hline
\end{tabular}




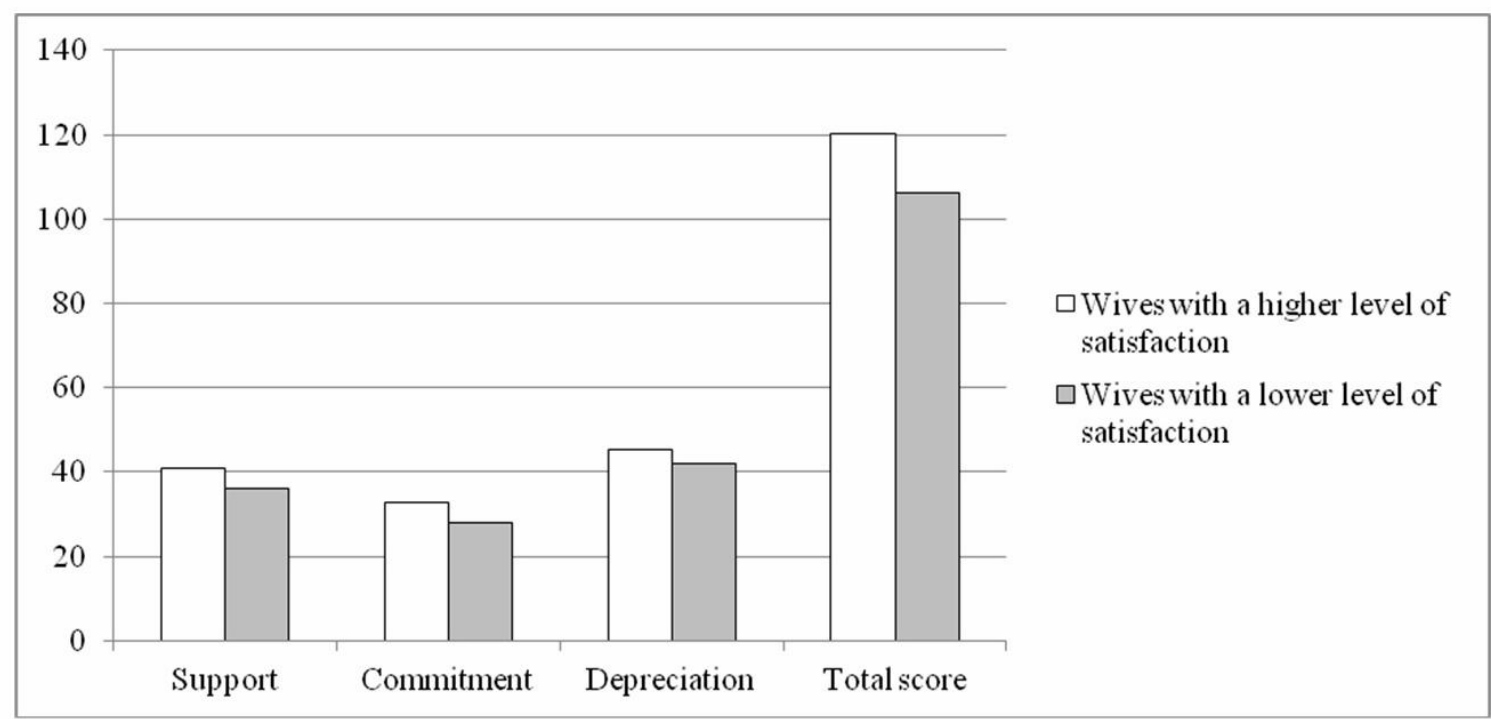

Chart 1. Graphic presentation of marital communication of wives with a higher and lower level of satisfaction with their marriage

Taking into account the total score, the marital communication of wives with a higher level of satisfaction with their marriage is much better that the communication of wives with a lower level of satisfaction: $t(58)=3.79 ; p<0.01$. The same regularity was found in the case of particular scales referring to marital communication: support - $t(58)=2.72 ; p<0.01$; commitment $-t(58)=3.48 ; p<0.01$; depreciation $-t(58)=1.97 ; p<0.05$.

Taking into account the total score, the marital communication of husbands with a higher level of satisfaction with their marriage is much better that the communication of husbands with a lower level of satisfaction: $t(58)=2.52 ; p<0.01$. A similar regularity was found in the case of particular scales referring to marital communication: support $t(58)=3.37 ; p<0.01$, and commitment $-t(58)=2.41 ; p<0.02$. No differences reaching the level of statistical significance were found between the studied groups of husbands in the case of depreciation.

Table 3. Marital communication of husbands with a higher and lower level of satisfaction with their marriage

\begin{tabular}{|l|c|c|c|c|c|c|}
\hline \multirow{3}{*}{ Scale } & \multicolumn{2}{|c|}{$\begin{array}{c}\text { Husbands with a } \\
\text { higher level of } \\
\text { satisfaction (N=30) }\end{array}$} & \multicolumn{2}{c|}{$\begin{array}{c}\text { Husbands with a } \\
\text { lower level of } \\
\text { satisfaction (N=30) }\end{array}$} & \multicolumn{2}{c|}{ Significance of differences } \\
\cline { 2 - 7 } & $\mathrm{M}$ & $\mathrm{SD}$ & $\mathrm{M}$ & $\mathrm{SD}$ & $\mathrm{t}$ & $\mathrm{p}<$ \\
\hline Support & 42.47 & 3.91 & 37.70 & 6.68 & 3.37 & 0.01 \\
\hline Commitment & 32.53 & 4.96 & 29.20 & 5.71 & 2.41 & 0.02 \\
\hline Depreciation & 44.47 & 5.79 & 43.13 & 7.63 & 0.76 & n.a. \\
\hline Total score & 119.47 & 10.73 & 110.37 & 16.61 & 2.52 & 0.01 \\
\hline
\end{tabular}




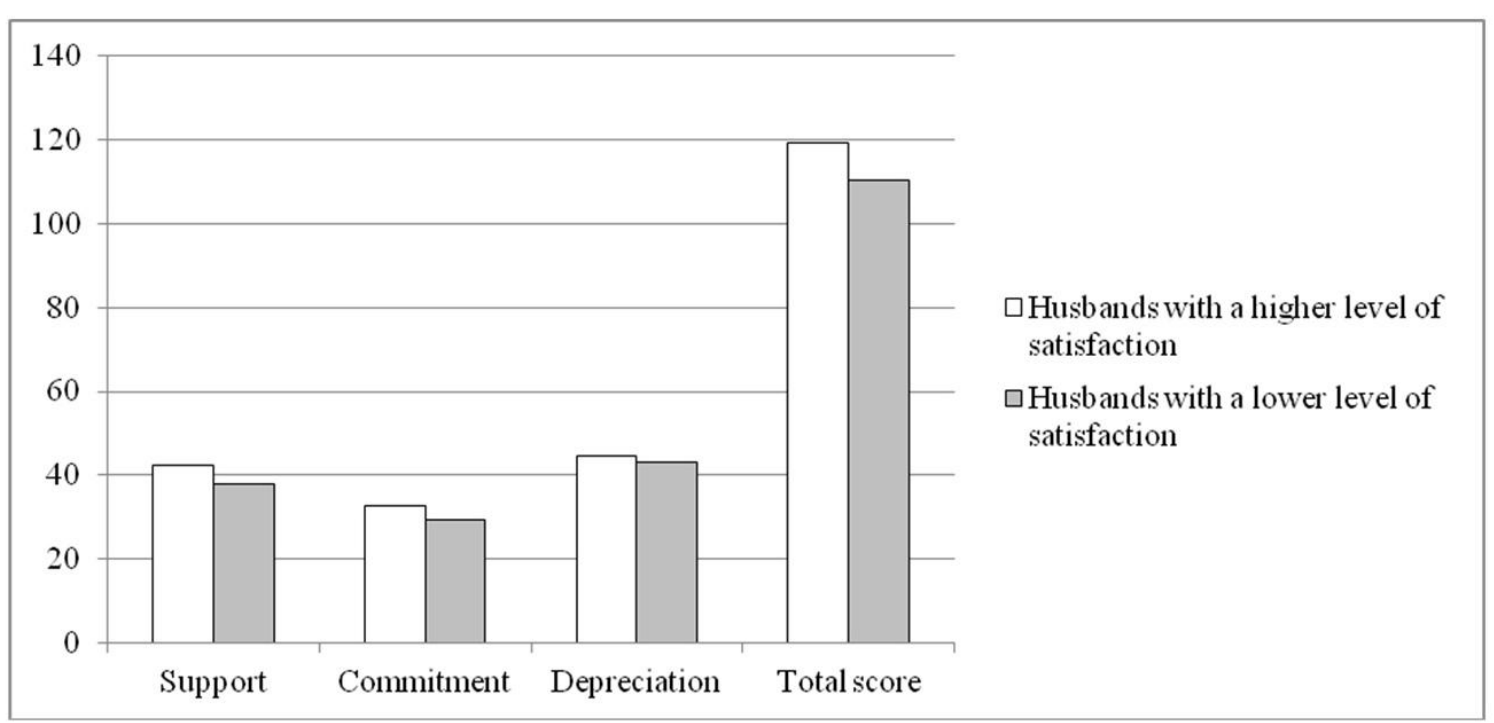

Chart 2. Graphic presentation of marital communication of husbands with a higher and lower level of satisfaction with their marriage

\section{Summary and interpretation of results}

The assumption of a higher quality of marital communication of spouses with a higher level of satisfaction with their marriage was fully confirmed as regards the total score, which is mostly saturated with two dimensions of marital communication: support and commitment. Support is showing the partner respect in daily life together by means of appreciating their efforts and displaying interest in their needs and problems, which you actively try to solve together (Plopa, 2005, p. 129). Commitment is related to creating the atmosphere of mutual understanding and intimacy in the marriage by showing affection to each other, stressing the uniqueness and importance of your spouse, breaking the everyday routine, and the tendency to prevent conflicts in the relationship (Plopa, 2005, p. 130). Experiencing respect and understanding from your partner makes you want to reciprocate (Pupin, Waldmajer, 2013) and engage in the relationship to a greater extent (Chmielewska, 2019). This motivates you to build the relationship together despite the need to make effort, because the benefits increase the sense of life satisfaction (Olearczyk, 2020). This takes place i.a., in the area of professional activity. Wives are more often willing to sacrifice their engagement in roles connected with work in order to fulfill marital and family roles (Mandal, 2008, p. 163). Husbands, in turn, draw greater satisfaction from fulfilling professional that family roles. "The high level of identification with the job that characterizes men contributes to higher self-esteem and gives them many other material benefits, thus allowing them to invest more time in marital and family roles" (Rostowska, 2008, p. 182).

Spouses with a higher and lower level of satisfaction with their marriage differ the least in the dimension of depreciation in marital communication. Depreciation is the display 
of aggression toward the partner, the lack of respect for their dignity, as well as the wish to dominate and control their actions (Plopa, 2005, p. 130). Husbands from both groups do not differ in this respect at the level of statistical significance. It can be explained with the fact that men do not have enough opportunities in the course of developing communication competences to achieve more satisfactory results. For cultural reasons, men experience the reinforcement of strength, independence, and coarseness (Siwiak, 2020). These traits, becoming part of the masculine identity, affect their way of communicating with women (Biedroń, 2012). Positive changes in this regard would be possible if more attention was given to expressing themselves and communicating with others in the process of raising boys in families (Skreczko, 2017), school education (Nowotarska, 2018) and direct preparation to marriage (Dullak, 2020). Care for dialog in marital daily life understood as a long-term process undoubtedly offers the greatest chance to make it satisfying for both partners, as with the passing of time there will be less and less aggression, violation of dignity, wish to dominate or control the actions of the spouse. Constantly updated and expanded knowledge about the spouse allows to plan future actions that will improve the quality of interpersonal communication (Dakowicz, 2012).

Wives with a higher level of satisfaction with their relationship had higher results in the dimension of depreciation than wives with a lower level of satisfaction. The difference was at the level of statistical significance of $p<0.05$. The reason for that may be a greater sense of security, resulting in the tendency to express themselves directly under the influence of strong emotions, which are not controlled by the cognitive sphere. It may be that elements of depreciation in communication of spouses are a constant signal to try to improve the marital dialog. The quality of the dialog will be better and better all the time, but it will never become perfect enough to cease to be a current challenge for the spouses (Kuryś, 2012, p. 28).

\section{Conclusion}

Marital communication is one of important factors influencing the spouses' sense of satisfaction with their relationship. Three dimensions of marital communication were analyzed in the presented study: support, commitment, and depreciation, which generally were higher in spouses satisfied with their marriage than in spouses with a lower level of satisfaction with the relationship. As part of caring for the good condition of future marriages, it is worth focus on developing social competencies in adolescents, especially those connected with providing support and interpersonal engagement, and especially the development of forms of expressing oneself in contact with another person that would be free from aggression, the wish to dominate, control or violate their dignity. 


\section{Bibliography:}

Adler, R.B., Rosenfeld, L.B., Proctor II, R.F. (2007). Relacje interpersonalne. Proces porozumiewania się, Poznań: Dom Wydawniczy REBIS Sp. z o.o.

Biedroń, M. (2012). Wybrane przykłady pozawerbalnego komunikowania władzy i dominacji w parach małżeńskich oraz kohabitujących, (in:) A. Mitręga,

I. Jagoszewska (eds.), Komunikacja jako narzędzie (po)rozumienia we wspólnotach społecznych, 29-48, Torun: Wydawnictwo Adam Marszałek.

Braun-Gałkowska, M. (1985). Miłość aktywna. Psychiczne uwarunkowania powodzenia w matżeństwie, Warszawa: Instytut Wydawniczy PAX.

Braun-Gałkowska, M. (2007). Poznawanie systemu rodzinnego, Lublin: Wydawnictwo KUL.

Braun-Gałkowska, M. (2020). Sprawy drobne, Lublin: Pewne Wydawnictwo.

Breton, H. (2020). Poradnictwo i doradztwo dla dorosłych. Paradygmat narracyjny, Studia Poradoznawcze, 9, 13-24.

Chmielewska, M. (2019). Rola miłości w budowaniu wysokiej jakości związku małżeńskiego, (in:) E. Chodźko, M. Śliwa (eds.), Motyw miłości w literaturze polskiej i obcej, 270-286, Lublin: Wydawnictwo Naukowe TYGIEL.

Chrost, M. (2020). Więź małżeńska jako doświadczanie miłości w ujęciu chrześcijańskim, Studia Paedagogica Ignatiana, 1 (23), 51-68.

Chrząstowski, Sz. (2020). Konflikty w parze w perspektywie narracyjnej terapii więzi, Psychoterapia, 3 (194), 31-44.

Cobb, R., Sullivan, K.T. (2015). Relationship education and marital satisfaction in newlywed couples: A propensity score analysis, Journal of Family Psychology, 29, 667-678.

Cypryańska, M., Bedyńska, S. (2013). Testy $t$-Studenta i ich nieparametryczne odpowiedniki, (in:) S. Bedyńska, M. Cypryańska (eds.), Statystyczny drogowskaz 1. Praktyczne wprowadzenie do wnioskowania statystycznego, 159-193, Warszawa: Wydawnictwo Akademickie Sedno Spółka z o.o.

Dakowicz, A. (2002). Poczucie bezpieczeństwa u osób o różnym typie płci psychologicznej, Psychologia Rozwojowa, 2, 51-59.

Dakowicz, A. (2012). Wiedza na temat współmałżonka w małżeństwach zadowolonych i niezadowolonych ze swojego związku, (in:) A. Mitręga, I. Jagoszewska (eds.), Komunikacja jako narzędzie (po)rozumienia we wspólnotach społecznych, 49-58, Torun: Wydawnictwo Adam Marszałek.

Dakowicz, A. (2013). Psychologiczna analiza funkcjonowania małżeństw zróżnicowanych wyznaniowo, (in:) J. Muszyńska, W. Danilewicz, T. Bajkowski (eds.), Kompetencje międzykulturowe jako kapitał społeczności wielokulturowych, 255-268, Warszawa: Wydawnictwo Akademickie Żak. 
Dakowicz, A. (2014). Powodzenie matżeństwa. Uwarunkowania psychologiczne w perspektywie transgresyjnego modelu Józefa Kozieleckiego, Białystok: Wydawnictwo Uniwersyteckie TRANS HUMANA.

Dakowicz, A. (2020). Psychotransgresyjna analiza sfery emocjonalnej małżonków o wyższym i niższym poziomie zadowolenia ze swojego związku, (in:) M. Sroczyńska, A. Linek (eds.), Społeczne konteksty wspótbycia i intymności. Szkice z socjologii emocji. Tom I, 145163, Warszawa: Wydawnictwo Naukowe UKSW.

Dullak, K. (2020). Przygotowanie bliższe do małżeństwa w świetle dokumentów różnych szczebli w wybranych diecezjach polskich, Studia Koszalińsko-Kołobrzeskie, 27, 527-543.

Erus, S.M., Deniz, M. E. (2020). The mediating role of emotional intelligence and marital adjustment in the relationship between mindfulness in marriage and subjective wellbeing, Pegem Eğitim ve Öğretim Dergisi, 2 (10), 317-354.

Hill, W.D., Arslan, R.C., Xia, C., Luciano, M., Amador, C., Navarro, P., Hayward, C., Nagy, R., Porteous, D.J., McIntosh, A.M., Deary, I.J., Haley, C.S., Penke, L. (2018). Genomic analysis of family data reveals additional genetic effects on intelligence and personality, Molecular Psychiatry, 12 (23), 2347-2362.

Jabłońska, I. (2020). Rola dialogu w życiu człowieka, Kwartalnik Naukowy Fides et Ratio, 4 (44), 121-131.

Janicka, I. (2010). Jakość małżeństw poprzedzonych kohabitacją, (in:) T. Rostowska, A. Peplińska (eds.), Psychospołeczne aspekty życia rodzinnego, 94-109, Warszawa: Difin SA.

Janicka, I., Cieślak, M. (2020). Satysfakcja seksualna i jej znaczenie w bliskich związkach emocjonalnych, Polskie Forum Psychologiczne, 4 (25), 389-405.

Jankowiak, B., Waszyńska, K. (2011). Współczesne formy życia partnerskiego. Analiza jakości i trwałości relacji, Nowiny Lekarskie, 5 (80), 358-366.

Jaworowska, A., Matczak, A. (2001). Kwestionariusz Inteligencji Emocjonalnej INTE N.S. Schutte, J.M. Malouffa, L.E. Hall, D.J. Haggerty'ego, J.T. Cooper, C.J. Goldena, L. Dornheim. Podręcznik, Warszawa: Pracownia Testów Psychologicznych Polskiego Towarzystwa Psychologicznego.

Juroszek, W. (2017). Wybór współmałżonka - aspekt zadaniowy, ewolucjonistyczny i planowy, Kwartalnik Pedagogiczny, 2 (62), 153-167.

Kornas-Biela, D. (2012). Kiedy seks prowadzi do szczęścia? (in:) I. Ulfik-Jaworska, A. Gała (eds.), Dalej w te sama stronę. Księga Jubileuszowa dedykowana Profesor Marii BraunGałkowskiej, 441-459, Lublin: Wydawnictwo Katolickiego Uniwersytetu Lubelskiego.

Kuryś, K. (2012). Porozumienie w małżeństwie jako narzędzie rozumienia, (in:) A. Mitręga, I. Jagoszewska (eds.), Komunikacja jako narzędzie (po)rozumienia we wspólnotach społecznych, 17-28, Torun: Wydawnictwo Adam Marszałek. 
Kuryś-Szyncel, K., Błachnio, A. (2020). Krytyczne wydarzenia życiowe i ich znaczenie w biografiach seniorów, Nauki o Wychowaniu. Studia Interdyscyplinarne, 1 (10), 114-136.

Lengua, L.J., Gartstein, M. A., Prinzie, P. (2019). Temperament and personality trait development in the family: Interactions and transactions with parenting from infancy through adolescence, (in:) D.P. McAdams, R.L. Shiner, J.L. Tackett (eds.), Handbook of personality development, 201-220, The Guilford Press.

Mahoney, A., Flint, D.D., McGraw, J.S. (2020). Spirituality, religion, and marital/family issues, (in:) D.H. Rosmarin, H.G. Koenig (eds.), Handbook of Spirituality, Religion, and Mental Health, 159-177, Elsevier Academic Press.

Mandal, E. (2004). Podmiotowe i interpersonalne konsekwencje stereotypów zwiazanych z ptcia, Katowice: Wydawnictwo Uniwersytetu Śląskiego.

Mandal, E. (2008). Miłość, władza i manipulacja w bliskich związkach, Warszawa: Wydawnictwo Naukowe PWN SA.

Nowotarska, P. (2018). Płciowość jako kategoria pedagogiczna, Chowanna, 1 (50), 303-324.

Olearczyk, T. (2020). Cisza w dialogu rodzinnym, Roczniki Pedagogiczne, 4 (48), 45-61.

Otero, M.C., Wells, J.L., Chen, K-H., Brown, C.L., Connelly, D.E., Levenson, R.W., Fredrickson, B.L. (2020). Behavioral indices of positivity resonance associated with long-term marital satisfaction, Emotion, 7 (20), 1225-1233.

Paprzycka, E., Mianowska, E. (2020). Nietrwałość związków intymnych - społecznodemograficzne uwarunkowania powodów potencjalnej decyzji o rozstaniu kobiet i mężczyzn, Przegląd Socjologiczny, 1 (69), 81-105.

Plopa, M. (2005). Psychologia rodziny. Teoria i badania, Elbląg: Wydawnictwo Elbląskiej Uczelni Humanistyczno-Ekonomicznej.

Pupin, Z., Waldmajer, J. (2013). Komunikacyjne zachowania w małżeństwie z perspektywy własnej i partnera, Family Forum, 3, 187-200.

Pyźlak, G. (2020). Troska o rodziny w sytuacjach trudnych, Rzeszów: Wydawnictwo BONUS LIBER.

Raley, R.K., Sweeney, M.M. (2020). Divorce, Repartnering, and Stepfamilies: A Decade in Review, Journal of Marriage and Family, 1 (82), 81-99.

Rawicka, I., Rzepa, T. (2017). Cechy temperamentalne a satysfakcja ze związku, Polskie Forum Psychologiczne, 4 (22), 623-635.

Rostowska, T. (2003). Dojrzałość osobowa jako podstawowe uwarunkowanie życia małżeńskiego i rodzinnego, (in:) I. Janicka, T. Rostowska (eds.), Psychologia w stużbie rodziny, 45-55, Łódź: Wydawnictwo Uniwersytetu Łódzkiego.

Rostowska, T. (2008). Małżeństwo, rodzina, praca a jakość życia, Kraków: Oficyna Wydawnicza "Impuls".

Rucki, M. (2020). Program formacyjny Ruchu Wiernych Serc jako propozycja sposobu wyjścia z kryzysu, Teologia i Człowiek, 3 (51), 179-196. 
Ryś, M., Greszta, E., Grabarczyk, K. (2019). Intelektualna, emocjonalna i działaniowa bliskość małżonków a ich gotowość do rozwiązywania konfliktów oraz przebaczania, Kwartalnik Naukowy Fides et Ratio, 2 (38), 221-254.

Ryś, M., Sztajerwald, T. (2019). Psychologiczne aspekty dojrzałości młodych do małżeństwa. Skala Dojrzałości Psychicznej do Małżeństwa SKALDOM II, Kwartalnik Naukowy Fides et Ratio, 1 (37), 158-183.

Siemiątkowska, K., Obrębska, M. (2020). Jakość komunikacji w związku a kompensująca rola aktywności w sieci, Człowiek i Społeczeństwo, 50, 127-138.

Siwiak, A. (2020). Przestrzeń bez końca, Czas Kultury, 1 (36), 73-80.

Skreczko, A. (2017). Współczesne wyzwania w wychowaniu do miłości małżeńskiej, Sympozjum, 1 (32), 49-67.

Sorkowicz, A. (2021). Nauczanie Kościoła katolickiego o małżeństwie i rodzinie a wybrane wyzwania związane z rodzicielstwem, Kwartalnik Naukowy Fides et Ratio, 1 (45), 49-65.

Szyszka, M. (2020). Znaczenie małżeństwa i rodziny współcześnie, (in:) M. Bieńko, M. Rosochacka-Gmitrzak, E. Wideł (eds.), Obrazy życia rodzinnego i intymności, 57-68, Warszawa: Wydawnictwa Uniwersytetu Warszawskiego.

Trębicka, P., Cichocka, A. (2019). Spirituality, religiosity and satisfaction in a romantic relationship, Kwartalnik Naukowy Fides et Ratio, 2 (38), 213-221.

Ulfik-Jaworska, I. (2012). Psychospołeczne aspekty narzeczeństwa. Przegląd badań prowadzonych pod kierunkiem Profesor Marii Braun-Gałkowskiej, (in:) I. UlfikJaworska, A. Gała (eds.), Dalej w te sama strone, 89-111, Lublin: Wydawnictwo Katolickiego Uniwersytetu Lubelskiego.

Ulfik-Jaworska, I. (2015). Kohabitacja przedmałżeńska a jakość i trwałość związku małżeńskiego, (in:) W. Muszyński (ed.), Rodzina jako wartość: wzory - modele redefinicje, 116-131, Torun: Wydawnictwo Adam Marszałek.

Wańczyk-Welc, A.E. Marmola, M. (2020). Relacje w rodzinie pochodzenia a jakość małżeństwa u rodziców dzieci w wieku przedszkolnym, Kwartalnik Naukowy Fides et Ratio, 1 (41), 206-223.

Weryszko, M. (2012). Jakość komunikacji między narzeczonymi a poziom ich zadowolenia ze związku małżeńskiego. Badania podłużne, (in:) I. Ulfik-Jaworska, A. Gała (eds.), Dalej w tę sama stronę, 157-167, Lublin: Wydawnictwo Katolickiego Uniwersytetu Lubelskiego.

Weryszko, M. (2020a). Miłość małżeńska - uwarunkowania powodzenia fundamentalnej relacji w rodzinie, Kwartalnik Naukowy Fides et Ratio, 1 (41), 129-143.

Weryszko, M. (2020b). Komunikacja interpersonalna jako esencja interakcji społecznych, Kwartalnik Naukowy Fides et Ratio, 2 (42), 253-268.

Wojciszke, B. (2017). Psychologia mitości. Intymność, namiętność, zobowiązanie, Gdańsk: Gdańskie Wydawnictwo Psychologiczne.

Wołpiuk-Ochocińska, A. (2020). Kobiecość i męskość i role z nim związane w opinii osób różniących się płcią psychologiczną, Kwartalnik Naukowy Fides et Ratio, 1 (41), 144-164. 